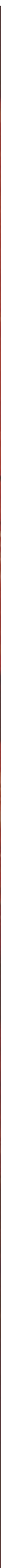




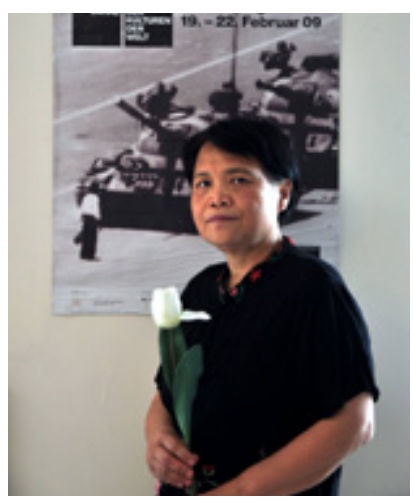

Ai Xiaoming. PC: China Digital Times.

\section{Jiabiangou Elegy A Conversation with Ai Xiaoming}

ZENG Jinyan

Defore retiring, Ai Xiaoming was a Professor in the Chinese Department at Sun Yat-sen University. She is also a feminist scholar, rights activist, and independent documentary filmmaker. In the 1980s and 1990s, Ai's academic work focussed on modern and contemporary Chinese literature and comparative literature. In 1999, she moved to the United States for one year to conduct research on women and gender studies. After returning to China, she continued to focus on women, gender, and literature. Since 2003, she has actively participated in feminist/citizen activism, and independent documentary filmmaking. Her well-known documentary film works include Garden in Heaven (天堂花园, 2005), The Taishi Village (太石村, 2005), The Epic of the Central Plains (中原纪 事, 2006), Our Children (我们的娃娃, 2009), and Three Days in Wukan (乌坎三日, 2012). In 2010, she was awarded the 'Simone de Beauvoir Prize' along with women rights activist Guo Jianmei. Ai's latest documentary Jiabiangou Elegy: Life and Death of the Rightists (夹边沟祭事) was premiered in Hong Kong in 2017 at the Chinese Independent Documentary Lab.

Jiabiangou Elegy brings to focus the tragic deaths of inmates inside the Jiabiangou labour camp and the aftermaths of this tragedy. In 1957, in the wake of the Anti-rightist Campaign, the Chinese authorities sent more than 3,000 people to this labour camp in Jiuquan, Gansu province. These people were classified as rightists, counterrevolutionaries, and anti-Party. In three years of re-education through labour (劳教, laojiao), more than 2,000 people died of abuse and starvation. Only a few hundred survived. In 2014, Ai Xiaoming began filming the stories of the few remaining survivors of Jiabiangou, as well as those of the children of the victims. She also tracked down the cadres in charge of the labour camp and their descendants in an attempt to understand the inner workings of the re-education through labour system, as well as the causes of the Great Famine of the late 1950s from a different perspective. Several of these interviewees passed away during the filmmaking process. 
Ai Xiaoming: At first, I thought there was nothing new to say about Jiabiangou. Stories have been written, and movies such as Wang Bing's The Ditch (夹边沟, 2010) and Fengming: A Chinese Memoir (和凤鸣, 2007) have been made [in 2018, Wang Bing also premiered Dead Souls (死魂灵), another documentary about Jiabiangou, Translator's Note (TN)]. The filmmaker $\mathrm{Hu}$ Jie also documented Jiabiangou. So, I was asking myself: should I still undertake this project even though others have already done it? However, as you can see from the beginning of the film [the movie begins with the smashing of the memorial for the victims of the labour camp and official obstruction of a commemorative ceremony, $T N]$, my encounter with this subject is rooted in contemporary reality. We are people of 'the present' who have come to pay homage to the victims of Jiabiangou. We enter Jiabiangou from our own emotional perspectives instead of simply dealing with it as a historical subject.

As the filming and editing of the film progressed, this became more and more apparent. Jiabiangou is not a distant event of the past: its shadow still shrouds our lives, perhaps more so than ever. For example, we still experience difficulties when speaking our mind because our freedom of speech has been suppressed; innocent people were convicted of crimes they did not commit because neither civil nor political rights are guaranteed in China. Even asking the National People's Congress to ratify the two United Nations conventions on civil and political rights has been considered a crime.

How to evaluate the history of the Mao era is a question that we face today. In the fifth section of Jiabiangou Elegy, entitled 'Where the Soul Lies' (魂归何处), there is a segment in which we showed the emotional outburst of Mr Zhang Suiqing, the initiator of the memorial for the victims. He raised a crucial point: from the sabotage of the memorial, you can see the violent resurgence of the 'hit, smash, loot' habits of the Cultural Revolution. This is the dire situation we face now. We must not ignore it. We must think about where the danger lies and how serious it is. The fact that the memorial for the victims of Jiabiangou has been destroyed has both real and symbolic meanings. It signifies that those in power want to prevent people from facing history by silencing discussions on the cause of this tragedy. The issue of autocracy still remains: it was unresolved in the past and remains unresolved in the present.

In making this documentary, I was not experiencing the past, but the present. We were denied permission to enter Jiabiangou and to pay homage to the deceased. It was as if there was some kind of secret code embedded in that part of history and the 
authorities did not want us to decode it. I felt that if this really was a secret that cannot be discussed openly, it showed that the forces that threaten our everyday life still exist. Recalling loved ones and mourning the dead is a normal expression of human nature: how could the victims of this tragedy be deprived of their memories and commemorations?

This documentary also explores the theme of memory, as many stories exist solely in the memories of those who have lived through them. On the other hand, I have also witnessed that in order to survive and maintain sanity in old age, some victims have attempted to supress their memories, reshaping them to fit the framework of the official ideology. Anything to do with the Anti-rightist Campaign, reeducation through labour, hunger, and death have been constrained and distorted by the official ideology into the simple case of a 'mother beating a child'.

These are all forced distortions of personal memory: only when we get rid of these constraints and let people tell their personal stories, will we see an alternative history. I am not saying that there is some sort of absolute or unifying truth, but that there are true stories which have been supressed and cannot be communicated through language. We must enter into the voids of history. Although people like Hu Jie, Wang Bing and others have already done so, the void is bottomless. We need to find the language of personal memories and transmit those lost stories to the world.

ZJY: You have openly talked about the difficulties of making documentaries on previous occasions. What kind of difficulties did you face in representing the visual images on screen in this project?

AXM: The events at Jiabiangou occurred over 50 years ago, but I hope that the audience will be able to envision the environment at that time. I started filming in 2014 and it took around two and a half years to finish. In 2017, however, it was the $60^{\text {th }}$ anniversary of the Anti-rightist Campaign. The terrain around Jiuquan, Gansu, has changed a lot, and Jiabiangou today is no longer a desolate place. It is now the location of Jiabiangou Forest Park. My guides, associates, and I went a long way to film the desert in its original state, including its different faces in the four seasons. Without this footage, the film would have become a mere interview. Our basic method was shooting on site and, thanks to this, we did make some new discoveries. We went to Gongpoquan in Majiashan, Shanxi province, to film the labour camp there, which supplemented our records on Jiabiangou because no one has previously disclosed the fact that a group 
of laojiao victims from Jiabiangou were sent to smelt iron at the border around 400 kilometres away. Many people died there. It took us an entire day to get there from Jiuquan, but in the end the place only appeared for less than 30 seconds in the documentary. I think this is the visual value of our film. While the audience may see it as just another shot, certainly less glamorous than a Hollywood movie, we actually shot that footage on site. In other words, we put hard work into relaying audio and visual evidence related to this case.

ZJY: In your film, some characters have great storytelling skills. Do you think they were able to bring the audience into the reality of how life was at that time?

AXM: I think a person's vivid story-telling ability does not necessarily indicate that what they are telling is the truth. What is more important is that when people enter into their genuine memories, we can see the state of their character and life. That state is real. From their words, the audience can feel and judge for themselves whether their stories are credible, how they experienced the past, and the kind of disasters they have witnessed. Even if a documentary is made up entirely of interviews with people, as long as the interviews are in-depth, the audience can still feel the importance of personal stories and will be attracted to the inner emotions of the narrator.

ZJY: Everyone has their own version of truth, making it a problematic concept to capture in a film like this. What does truth mean to you here, and what do you feel is the truth of Jiabiangou?

AXM: As I have said before, there is no such thing as absolute truth. Truth is the experience of individuals. It is also expressed differently since people's political experience and suffering are different. Ideology will always reinforce a certain kind of interpretation and only the explanations sanctioned by those in power are safe. Individuals who talk about the past based on their own experiences and understandings are at risk. Under such circumstances, you must explain the past in a tone that is politically correct and respects authority, rather than using the experience of your own life. With regard to the 'truth' of Jiabiangou, the most common explanation is that of the "mother beating the child'-once she has admitted that she wrongfully beat you, the best choice for you is to just move on.

No one is stupid. The tragedies caused by dictators are well understood by everyone, including those in charge. Yet people are still frightened to speak up, because the social mechanisms that punish freedom of speech remain the same. This twisted 
Stockholm Syndrome is widespread in China. Those who control society still have the power to decide on the life or death of a person. If you do not 'embrace' them, you will have no security, to the point where you could even lose the most basic conditions necessary for life itself. Under these circumstances, the victims have no way to form their own subjectivity. The 'mother beating the child' rhetoric is a barrier, a helmet, and an amalgamate of many other explanations such as: 'once a tragedy has happened, let's never speak of it again', or 'mistakes of the past were only partially wrong and have since been corrected'. Indeed, compared to the 1950s, people's freedom has increased, and thought monitoring has become far less harsh. However, the one-party autocracy and their tight grip on power have not changed. This is the essence of our society.

The survivors of Jiabiangou are getting older, and many are retreating further and further away from the public world. Some passed away while we were filming. But through the documentary, they were given a voice again. Today, each interviewee still faces the predicament of having no freedom of speech. They must make choices on whether or not to speak, on what to say, and on how much to say. Still, you have some people who say: 'If you turn off those cameras, I'll tell you.' People are outspoken in private, it is just when they face the public that their self-censorship mechanisms switch on.

The Jiabiangou labour camp has been dispersed, but the story did not end there. At the end of 2013, a group of survivors and families of the victims of the Anti-rightist Campaign in the neighbouring city of Lanzhou initiated a movement to establish a memorial at Jiabiangou. This received the support of many across the country, who sent in donations. However, the memorial was destroyed in less than two weeks after being erected, and public commemorations were banned. I had to deal with this ban throughout the filming process. This is why I believe that Jiabiangou Elegy is not purely a historical reflection, but also a representation of the present.

We have had many conflicting conversations with the past, and now we see these conflicts occurring in the present day. What we thought was the past has reappeared. We see largescale production of revolutionary songs in the music halls. We see how some continue to summon up the spectre of the Cultural Revolution, even using its concept to explain the growing economic inequality in our society, arguing that society can be transformed with Mao Zedong's theory of continuing revolution. I strongly believe that we are still haunted by the ghost of the Cultural Revolution. Therefore, Jiabiangou Elegy is an inquiry of the plights we face in today's society. Even just to start such an inquiry is extremely difficult in China: unlike the discussion of the Holocaust, whereby camps such as Auschwitz 
were closed, criminals were put on trial and sentenced, and the event continues to be commemorated, today in China we are faced with the same conditions and the inability to reflect on the event itself when we discuss the tragedy at Jiabiangou and the mistakes of the Anti-rightist Campaign.

ZJY: Apart from those difficulties you mentioned earlier, did you also experience any language difficulties when your interviewees spoke to you?

AXM: In everyday life, it is rare for people to express their pain through language. Mao-era indoctrination certainly did not allow for the description of the shortcomings of reality, let alone a portrayal of deep emotional pain. At the same time, the Mao era also praised an attitude of suffering-suffering is the manifestation of a true revolutionary spirit. We have all endured hard times, and we will take pride in facing hardship. It is like that saying by Mencius:

When Heaven is about to confer a great office on any man, it first exercises his mind with suffering, and his sinews and bones with toil. It exposes his body to hunger, and subjects him to extreme poverty. [Gaozi II, here in the translation by James Legge, $T N]$

The problem with this is that it conditions society to see suffering as a basic element of life. This is a unique symptom of totalitarian societies that seeks to eradicate the basic needs of its people, and look down upon their interests and hobbies. Even if life is filled with suffering, you must not say anything. Just like what Professor He Fengming said in the documentary: 'You can't say that you are hungry. If you say it, it would be an opposition to the Party's food policy.' This is a physical feeling, yet it is interpreted as anti-Party disobedience. This experience is indeed politically antagonistic and forces you to confront lies. But because many people choose to say nothing, as the years go on, they lose the very ability to speak.

Those in charge like to romanticise suffering, so that people can submit to them. Autocracies control people by creating a moral ideal for a utopia. In the case of communist autocracies, these ideals include creeds that demand you to dedicate your life to the collective and its goals, the leader, and the socialist system. Otherwise you have no significance, your life itself does not have value.

Furthermore, the system does not recognise the value of the individual and that life can be self-sufficient. The rights that mankind were born with have no place in the discourse of communist totalitarianism. People must abandon all this and 
let communism project onto their lives. This is the only way for life to have purpose. Because of such an interpretation of life, people rarely discuss pain. In fact, they have become adept at hiding pain. When we actually face pain, it places us in an uncomfortable situation. Looking back at these distortions and splits in their minds, people fall into a pit of self-humiliation. This may be one reason why they tend to not look back.

ZJY: Speaking about the relationship between past and present, do you think that your truth is directly related to your experience and your situation?

AXM: Yes and no. It is related in that I am also a person of that era. I have experiences from my childhood similar to those of the characters in the documentary. We were imbued by the same communist totalitarian discourse, and we worshipped the same leader. Very soon, young people like myself grew to become the 'young revolutionary forerunners' that they needed. We became fanatic adherents of the Cultural Revolution. And although the people I interviewed were older than me-more accurately, they were seniors in the same political movementwe are all survivors and witnesses of the same era. I do not have a feeling of disassociation with their experiences. In this regard, their stories were like the previous season to my own story.

When I conduct interviews, I first explain my own ideas to the interviewees to try to get them to understand, then I start filming with their consent. As I mentioned earlier, this was not too difficult, probably because the interviewees and I grew up in the same era. Similarly, when I interviewed researchers about the Great Famine, it was very easy for me to understand them. We have similar values, and continue to support each other. We are all survivors of the Mao era, and the political logic of that time is familiar to all who have lived through it.

The outcome of the same interview conducted by someone who was born in the 1980s or 1990s may have been quite different. They must overcome their own era, as the generations who came after the Cultural Revolution have their own personal experiences. Those who were born in the 1980s and 1990s have not seen hunger and poverty on such a scale, nor have they experienced a multitude of acts of class discrimination and political taboos. Conversations between contemporaries and those across different generations will be quite different. Plus, a younger director may choose to adopt different creative methods. I have not tried a dramatic approach yet. So far, I have made my films in a straightforward way. This could be my problem, or my limitation. 
ZJY: Does the 'truth' presented in your documentary have anything to do with your situation, including the fact that you were monitored $24 / 7$ and that government officials came to you and asked you not to shoot this film?

AXM: First, I will talk about how I and the people portrayed in the movie are different. Rightists are seen as dissidents, but in reality a lot of people are not actually dissidents. Many interviewees said that they were classified as a 'rightist' simply because they had a poor relationship with their superior in the work unit, or that it was purely because they needed people to make up the arbitrary quota for 'class enemies'. These people became adversaries, pushed to the bottom of society and suffered immensely. Such an experience is the awful fruit of class struggle.

ZJY: The famous 'rightist' Zhang Xianchi once said: 'They started by calling me a rightist, but they were wrong, because at that time I wasn't a rightist. I was then rehabilitated, but they were wrong again, as I have since actually became a rightist.'

AXM: A large number of people who were classified as 'rightists' truly loved the Communist Party at that time. Even now, some people still love the Communist Party, or at least that is what they say. They see the Party and the state as being 'our own'.

Like other political movements, the Anti-rightist Campaign was based on the principle of class struggle. In order to continue the struggle, even when there were no enemies, they had to create new ones to survive. The purpose was to consolidate power, to suppress different voices, and to create a sense of fear within society. Only when fear becomes absolute, can a dictatorship go unimpeded. Political movements are a tool to discipline society and to morph its values. Human tragedies are the high price we pay.

When we call someone a dissident today, we refer to the fact that they are politically critical. This is a consciously chosen act-all intellectuals must bear the burden of being in this position.

ZJY: Many interviewees in Jiabiangou Elegy talk about the inability and impossibility of resistance.

AXM: I think a lot of people considered resisting. But as someone in the film said: 'You can't even walk, how do you resist?' That person may have cursed the authorities from within, but there was absolutely no way to openly and effectively resist. I believe that if, hypothetically, we were put in the same position today, we would not be able to resist either. Moreover, 
you can also see this in today's society: if the authorities catch enough dissidents, the remaining ones will reconsider their own behaviour, as most people would not be able to bear the cost of going to prison.

ZJY: So what to do?

AXM: I think we can follow the example of human rights activists like Guo Feixiong and Tang Jingling who fought back with determination and paid the price for this, ending up in prison or under long-term soft detention. That is the answer to what to do.

ZJY: After the documentary series on the Sichuan earthquake, I feel that you are consciously shaping a new social personality through your films. Tan Zuoren [an environmental activist who in 2010 was sentenced to five years for 'inciting subversion of state power' for his activities to expose official malfeasance that led to the collapse of many schools during the earthquake, TN], the artist Ai Weiwei, and volunteers of the earthquake are all people with a new kind of personality.

AXM: These people hold up a new image of what it means to be a citizen. I have not used the concept of a 'new citizen' (新公民) but of a new 'citizen image' (公民形象). Compared to members of the public who are still unaware of their civil rights, these people have been awakened to their rights. In the documentary series on the Sichuan earthquake, we see that the most widely used concept was that of 'rights protection' (维权). Since my documentary Garden in Heaven, all the films I have produced follow those who are actively defending their rightswhether they are lawyers, scholars, artists who advocate for civil rights, or those who resist the deprivation of their rights, such as the parents of schoolkids who perished in the earthquake, people infected with HIV through blood transfusions, or villagers deprived of land. Their appeals are beyond their own interests, they advocate for all citizens to have rights. These are the rights-defending citizens that I have shown in my films. If you want to categorise them as 'new citizens', it is not incorrect.

This new citizen is based on a tolerant political ideal, i.e. the idea that the ruler will respond to the citizens' demands, recognise the defects of his governance, and make adjustments and improvements. As a result, people's efforts can bring about a real change. This fantasy has been shattered by the government's actions. The severe political pressure unleased through governmental response has made it clear that it is unshakeable, it does not need to listen, it has idolised itself. What happened in the past, the demonisation of those critical of the government, is taking place once again. 
ZJY: In other words, the fantasy was that citizens have the ability to force those in power to abide by the law and to promote social change. This is the ideal state of interaction between the government and the people.

AXM: Correct. After the Cultural Revolution, there was a saying called 'bringing order out of chaos' (拨乱反正). It was a government-led effort at 'correcting errors'. People support good governments, but it is difficult for individuals to participate in government decisions. The rise of the Internet has given people a platform to exchange ideas, and through that, they realised that civil participation can propel the government to shift from the 'rule of man' (人治) to 'good governance' (善治).

This understanding is a huge breakthrough in terms of selfawareness of the citizens. Many years of authoritarian rule have made people fearful of the government to such an extent that they did not dare to participate in public politics. The change brought about by the Sun Zhigang incident [the death of a young migrant as a result of physical abuse that he suffered while detained under China's custody and repatriation system back in $2003, T N]$ has made 'rights protection' into a positive thing in the public eye. The significance of being a citizen is that it puts you in a position to demand that the rights given to you in the law are fulfilled. This is the basis for the rise of the identity of being a citizen.

Conflicts between citizens and the government have traditionally been seen as a conflict of understandings-it is those in power who are wrong, not the system itself. The civil right movement is seen as a peaceful social movement, an exercise in citizens's self-education and self-awareness. Power's wickedness can be confronted, as long as the people's will to criticise is strong enough.

But today, it appears that such an imaginary is very naïve and has been greatly influenced by the doctrines of the Party-state. For example, Premier Wen Jiabao in the past called for fairness and justice, and so people took up this rhetoric and asked for fairness and justice. Now that this moderate approach has failed, people are forced to choose again. They must make adjustments to their past behaviours, ideals, and beliefs. Activists like Guo Feixiong, Tang Jingling, Xu Zhiyong, Pu Zhiqiang, Ai Weiwei, and others have all tried to appeal to the government's own system and discourse in an attempt to advance advocacy and dialogue. All of them have been smeared and punished, one after the other. It is now commonplace to charge people like them with the crime of 'inciting subversion of state power'. It is as if they cannot wait to revert back to the 50s. 
However, the ideas and actions of these 'new citizens' have nurtured a large number of people within society. The potential for a social movement still exists, we know that it is impossible to completely eradicate these movements. We can also see that many interest and rights groups, including veterans, have continued to petition, going to Beijing and handing in petitions as collectives. Some incidents have taken an even more dramatic form, such as the violent rebellions against demolitions. So despite the strict monitoring and deletion of social media posts, open political confrontation has not disappeared, in fact it has gained more influence. And as for those posts that directly challenge the one-party dictatorship, had it not been for the constant silencing, the criticisms would have gained more and more support.

\section{ZJY: Do you have any expectations for the audience of Jiabiangou Elegy?}

AXM: Every work has a life of its own. I believe that if this film succeeds in providing a detailed account of the tragedy at Jiabiangou, it will be useful for those who want to understand this particular period of history. But as for how people will use it, I do not know, because it is beyond my control.

I will give this movie to my fellow citizens, and the scholars and artists whom I come across. In these circles, people can view it and discuss it among themselves. I also hope that schools can have viewing sessions, and that university libraries can keep a copy. In short, it is a great regret that this documentary cannot be distributed freely and publically. I can only hope that people will continue to use it in their own way. It is like writing an article and then storing it in a database to which people can have access.

I believe that international viewers are free to watch this film. Viewers in Hong Kong and Taiwan can also see it. However, in a democratic society people's concerns may not be the same as ours. How much does our work have to do with them? For the average person, probably not a lot. For independent Chinese documentaries such as this, the audience is still largely domestic. Jiabiangou Elegy represents our current efforts to fight for a free and democratic society in China. The main participants of this movement are the people who the documentary addresses. 